\title{
Sensory profile of eleven peach cultivars
}

\author{
Perfil sensorial de onze cultivares de pêssegos
}

\section{Francine Lorena CUQUEL ${ }^{1 *}$, Charla Fátima Spezzatto de OLIVEIRA ${ }^{1}$, Osmir José LAVORANTI²}

\begin{abstract}
The goal of this study was to evaluate the sensory profile of eleven peach cultivars grown in an experimental orchard located in the city of Lapa (PR, Brazil) in two seasons. The peach cultivars analyzed were Aurora I, Chimarrita, Chiripá, Coral, Eldorado, Granada, Leonense, Maciel, Marli, Premier, and Vanguarda. The sensory analysis was performed by previously trained panelists; 20 of them in the first season and 10 in the second season. The sensory evaluation was performed using Quantitative Descriptive Analysis, in which the following attributes were measured: appearance, aroma, flesh color, flesh firmness, flavor, and juiciness. The results showed preference for sweet, soft, and juicy fruits. Chimarrita, Chiripá, and Coral fruits showed better sensorial performance than the other peach cultivars. It was also verified that the analysis of the attributes aroma, flesh firmness, and flavor is enough for performing the sensory profile of peach fruits for in natura consumption.

Keywords: Prunus persicae; stone fruit; hedonic test; post harvest.
\end{abstract}

\section{Resumo}

Este trabalho teve como objetivo avaliar o perfil sensorial de onze cultivares de pêssego produzidos em duas safras em um pomar experimental implantado na Lapa (PR, Brasil). Os cultivares analisados foram Aurora I, Chimarrita, Chiripá, Coral, Eldorado, Granada, Leonense, Maciel, Marli, Premier e Vanguarda. As análises sensoriais foram realizadas por julgadores previamente treinados, sendo 20 julgadores na primeira safra e 10 na segunda. O método de avaliação empregado foi a Análise Descritiva Quantitativa na qual foram mensurados os atributos aparência, aroma, cor de polpa, firmeza de polpa, sabor e suculência dos frutos. Os resultados obtidos demonstraram a preferência por frutos de sabor adocicado, com polpa macia e suculenta. Os cultivares Chimarrita, Chiripá e Coral obtiveram o melhor desempenho nas análises sensoriais. Foi verificado ainda que os atributos aroma, firmeza de polpa e sabor são considerados suficientes para a avaliação do perfil sensorial de frutos de pêssego para consumo in natura.

Palavras-chave: Prunuspersicae; fruta de caroço; teste hedônico; pós-colheita.

\section{Introduction}

Peach is the eighth most produced fruit in the world and one of the most consumed in natura (MATHIAS et al., 2008). Brazilian peach production is the $13^{\text {th }}$ worldwide with an area of 23.864 ha (AGRIANUAL..., 2007); however, it does not supply the internal market (SATO, 2001).

In the state of Paraná, only few peach cultivars are grown for the commercial purpose of in natura consumption, which leads to a restricted harvest period and consequently to a small profit margin due to the offer of concentrated products. An alternative to this problem is to grow other cultivars in order to produce fruits in different periods, which would also minimize eventual losses caused by late frost during the flowering stage or hail storm in the fruiting stage.

Peach consumers have become very demanding for fruit quality, mainly because of their health concerns (TIBOLA; FACHINELLO, 2004). Among the quality attributes appreciated by consumers, the most important are: flavor, aroma, flesh firmness, and appearance, which includes shape, size, and flesh color (KAYS, 1998). The goal of this research was to evaluate the sensory profile of eleven peach cultivars.

\section{Material and methods}

\subsection{Experimental orchard}

The experimental orchard was planted in the city of Lapa (PR/ Brazil), located at $25^{\circ} 46^{\prime} 02^{\prime \prime} \mathrm{S}$ and $49^{\circ} 42^{\prime} 10^{\prime \prime} \mathrm{W}$, in August 2003, with plants obtained from Rio Grande do Sul State (Brazil). The experiment was designed in beds, which consisted of three rows spaced $3 \mathrm{~m}$ apart. Three plants of each cultivar were randomly planted in each row, as follows: Aurora I, Chimarrita, Chiripá, Coral, Eldorado, Granada, Leonense, Maciel, Marli, Premier, and Vanguarda, spaced $80 \mathrm{~cm}$ apart totalizing 33 plants per row. The orchard was pruned using the ' $\mathrm{Y}$ ' system.

\subsection{Sampling}

In the 2006/2007 and 2008/2009 seasons, 20 fruits per plant were randomly harvested, making a total of 180 fruits per cultivar. The fruits with cream-colored epidermis were harvested when the peel was 40 to $60 \%$ reddish; as well as those with yellowish epidermis, which were harvested when the peel was 40 to $60 \%$ golden-yellow (CHITARRA; CHITARRA, 2005).

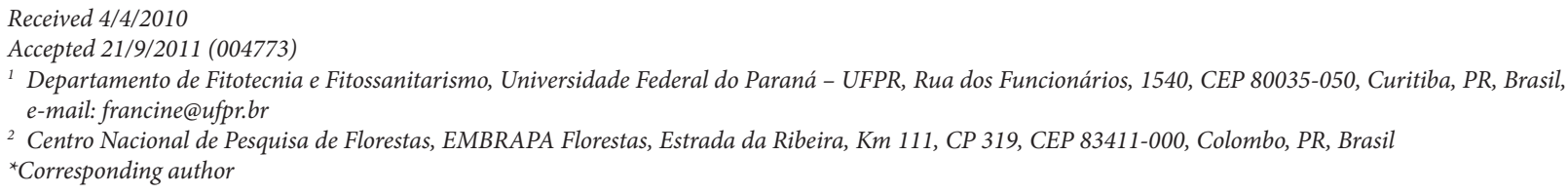


Immediately after harvest, all fruits were taken to the Laboratory, where they were stored in shelves for three days at $25^{\circ} \mathrm{C}$ and $65 \%$ of relative air humidity until sensory analysis.

\subsection{Sensory analysis}

Ethical clearance approval for this study was granted by the University' Research Ethics Committee. Forty assessors were pre-screened and trained based on availability, general food habits, ability to discriminate differences between products, and to describe their perceptions, according to the methodology described by Dutcosky (2007). The sensory panel that consisted of twenty selected and trained panelists consensually defined the descriptors showing similarities and differences for appearance, aroma, flesh color, flesh firmness, juiciness, and flavor. The sensory analysis was performed using Quantitative Descriptive Analysis (QDA) (STONE; SIDEL, 1985).

Sixty homogeneous fruits, caliber 4 or 5 , were selected for QDA and evaluated in triplicate taking into account the six descriptors described earlier. During the 2006/2007 season, the sensory analysis panel consisted of 20 panelists, and it consisted of 10 panelists during the 2008/2009 season. The reduction in the panelists' number in the second season was based on the sampling technique, which statistically demonstrated that 10 trained panelists were enough for this study. Each panelist received a sample of three fruits from each cultivar. The cultivars were analyzed during the harvesting period; therefore, a maximum of three cultivars were assessed per day. Between each sample analysis, the panelists were served crackers and mineral water.

\subsection{Data analysis}

Statistic analysis was performed using SAS Statistic Program (STATICAL...,1985); it consisted of multivariate analysis and grouping analysis.

\section{Results and discussion}

\subsection{Multivariate analysis}

In the 2006/2007 season, two factors explained $81.30 \%$ of the total variance (Table 1), which were represented by aroma, flesh firmness, and flavor. In the 2008/2009 season, it was also observed the presence of two factors, both of which explained $80.41 \%$ of the total variance (Table 1 ). However, these factors were represented by appearance, flesh color, flesh firmness, juiciness, and flavor. Except for the attribute aroma, all other attributes were significantly important to determine the sensory profile. This is in accordance with other authors who demonstrated that appearance, flesh color, flesh firmness, juiciness, and flavor are essential attributes for fruit acceptability (SAMS, 1998; MATTHEIS; FELLMAN, 1998; MARTINS et al., 2002; ROMBALDI et al., 2002).

With regard to flavor, in the 2006/2007 season, Chimarrita and Chiripá fruits were those who received higher sensory scores (Figure 1). These cultivars normally have high sugar content (ROMBALDI et al., 2001), which explains the preference expressed by the panelists for both cultivars (Figure 1). In the next season, in addition to Chimarrita and Chiripá, Coral fruits were also highly rated regarding flavor (Figure 2). Peach is characterized by high accumulation of soluble solids, responsible for its sweet taste (ROMBALDI et al., 2001), which is in accordance with one study carried out in Rio Grande do Sul State, in which $86 \%$ of the consumers preferred sweetish peaches (TREVISAN et al., 2006).

The 2006/2007 season had high aroma score in the sensory analysis. Peach aroma is mainly attributed to benzaldehyde and ketone, which are volatile compounds of great sensory significance (SUMITANI et al., 1994), and has been frequently correlated with flavor (SANDI et al., 2003), as verified here.

In the 2006/2007 season, Chimarrita and Chiripá fruits showed softer flesh than the other cultivars (Figure 1). In the next season, Marli and Premier, in addition to Chimarrita and Chiripá, also showed softer flesh. All these cultivars are recommended for in natura consumption (Figure 2) and are described in the literature as having soft flesh (RASEIRA; NAKASU, 1998; BIASI et al., 2004). It was observed that in both seasons most good flavor cultivars were those also with softer flesh. Considering that all fruits were harvested at the same ripening stage, such results demonstrate that consumers are likely to prefer peach with softer flesh, such as Chimarrita and Chiripá.

In both seasons, Granada, Vanguarda, Eldorado, Leonense, and Maciel showed firmer flesh (Figures 1 and 2), which explains why these cultivars are usually used for industrial purpose (RASEIRA; NAKASU, 1998). Furthermore, they also produce large fruits with acid flavor (RASEIRA; NAKASU, 1998), and therefore it is necessary to add sucrose and other sweetening compounds (EMBRAPA, 2009) to improve their flavor (TORALLES et al., 2006; MENDONÇA et al., 2005)

Leonense fruits with yellow flesh and peel had the best appearance and flesh color scores in the 2008/2009 season

Table 1. Factor analysis of eleven peach cultivars produced in the city of Lapa (PR, Brazil) in the 2006/2007 and 2008/2009 seasons.

\begin{tabular}{|c|c|c|c|c|c|c|c|}
\hline \multicolumn{4}{|c|}{$2006 / 2007$} & \multicolumn{4}{|c|}{$2008 / 2009$} \\
\hline Autovalor & $\begin{array}{c}\text { Total accumulated } \\
\text { variation }(\%)\end{array}$ & Variable & Comunality & Autovalor & $\begin{array}{c}\text { Total accumulated } \\
\text { variation }(\%)\end{array}$ & Variable & Comunality \\
\hline 1.4288 & 47.67 & Aroma & 0.7252 & 2.4984 & 49.97 & Appearance & 0.7698 \\
\hline 1.0101 & 81.30 & Flesh firmness & 0.9872 & 1.5220 & 80.41 & Flesh color & 0.7505 \\
\hline- & - & Flavor & 0.7264 & - & - & Flesh firmness & 0.7294 \\
\hline - & - & - & - & - & - & Juiciness & 0.9049 \\
\hline - & - & - & - & - & - & Flavor & 0.8657 \\
\hline
\end{tabular}


(Figure 2). A research carried out with peaches demonstrated that consumers associate fruit appearance with its sugar level (TREVISAN et al., 2006), which also influences their decision to buy the product (KAYS, 1991). This result is in accordance with the results obtained by Trevisan et al. (2006), who found that consumers prefer fruits with yellow flesh and peel to those with reddish or cream-colored peel.

Although Maciel and Leonense fruits, double-use cultivars, received good score for most attributes, they did not have as good flavor as the other cultivars (Figure 2).

Chimarrita, Coral and Chiripá fruits were very highly rated in the sensory analysis; they received the highest scores for the attribute flavor, essential in the for fruit quality analysis and consumers' preference (MATTHEIS; FELLMAN, 1998; CHITARRA; CHITARRA, 2005), as observed in Figure 2. These results are in accordance with those obtained in the analysis performed with the $2006 / 2007$ season cultivars, in which the Chimarrita and Chiripá cultivars were also highly rated regarding the attribute flavor, confirming the preference for fruits with sweet flavor to those with acid flavor for in natura consumption.

The results obtained demonstrated the preference for the consumption of sweet, soft and juicy in natura peach.

\subsection{Grouping analysis}

Observing the cultivars' grouping analysis in the 2006/2007 season (Figure 3), it is possible to verify that these cultivars' sensory profile meet the requirements for in natura consumption (Premier and Aurora I, Marli and Coral, Chimarrita and Chiripá). The same was also observed in the cultivars grown for industrial purpose (Granada and Vanguarda), as well as for those for double use (Maciel and Eldorado).

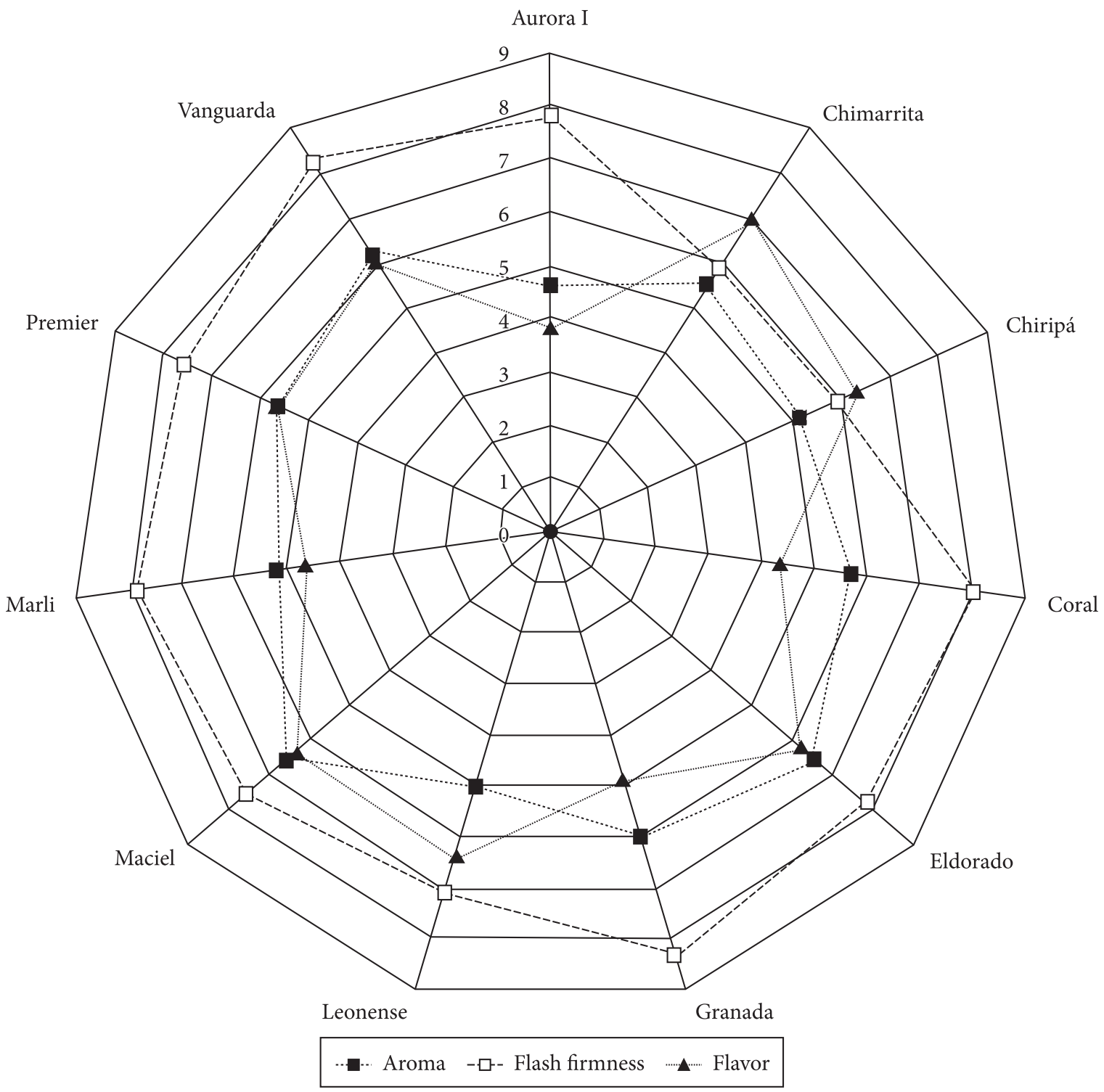

Figure 1. Sensory profile of eleven peach cultivars produced in the city of Lapa (PR, Brazil) in the 2006/2007 season and analyzed using Quantitative Descriptive Analysis. 


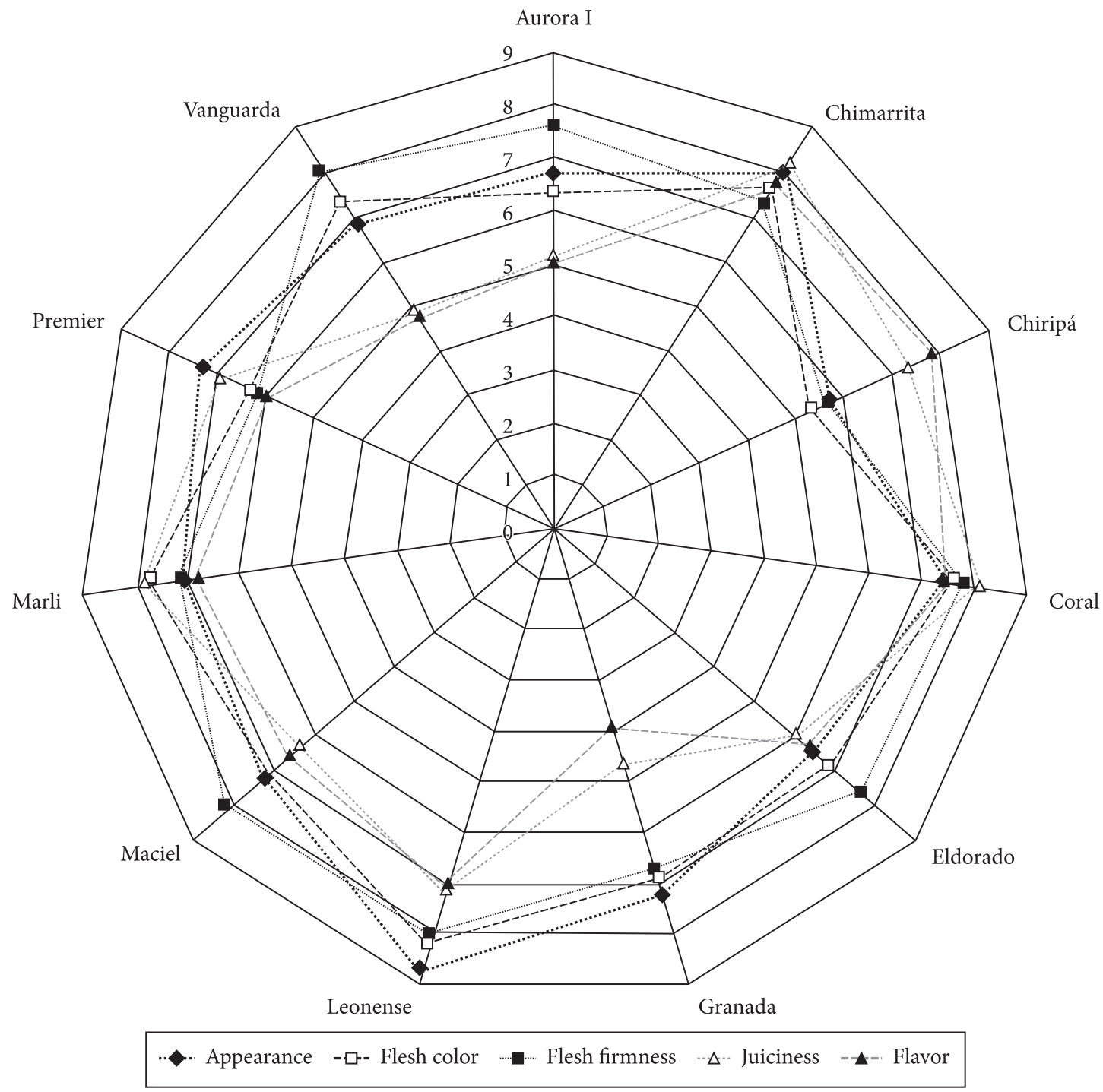

Figure 2. Sensory profile of eleven peach cultivars produced in the city of Lapa (PR, Brazil) in the 2008/2009 season and analyzed using Quantitative Descriptive Analysis.

Factors 1 and 2

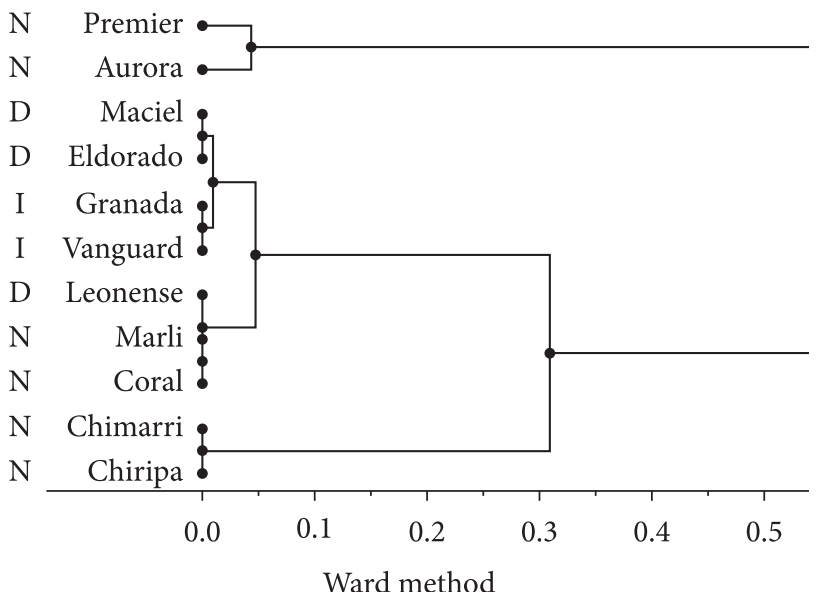

Figure 3. Dendrogram of grouping analysis plotted using the scores of the attributes flesh firmness, flavor, and aroma (Factors 1 and 2) obtained in the sensory analysis of eleven peach cultivars grown in the 2006/2007 season in the city of Lapa (PR, Brazil). N: in natura; D: double use, I: industry.
Peaches characteristics required for industrial purposes are mainly firm fleshed (CHITARRA; CHITARRA, 2005). Granada and Vanguarda fruits formed distinct groups (Figure 3), and demonstrated that flesh firmness, aroma, and flavor are important in the selection of cultivars for industry (Figures 1 and 2).

In the 2006/2007 season, Chimarrita and Chiripá cultivars did not fit in grouping formed by the Aurora I and Premier (Figure 3), for in natura consumption probably due to the better flavor attributed to the first group (Figure 2). In both seasons, Coral and Chimarrita, Maciel and Leonense, and Premier and Aurora I formed groups of cultivars with the same purpose demonstrating similarities between themselves (Figures 3 and 4 ).

In the 2007/2008 season, Granada and Chiripá, and Vangurada and Marli grouped different purposes (Figure 4). In this grouping, flesh color was also the only similarity found between the two cultivars; Marli received high scores for the attributes flavor and juiciness, but Vanguarda received lower scores. 
Table 2. Harvest period of eleven peach cultivars produced in the city of Lapa (PR, Brazil) during the 2006/2007 and 2008/2009 seasons.

\begin{tabular}{|c|c|c|c|c|c|c|c|c|}
\hline \multirow[t]{2}{*}{ Cultivars } & \multicolumn{2}{|c|}{ Oct. } & \multicolumn{2}{|c|}{ Nov. } & \multicolumn{2}{|c|}{ Dec. } & \multicolumn{2}{|c|}{ Jan. } \\
\hline & $01-15$ & $15-31$ & $01-15$ & $15-30$ & $01-15$ & $15-31$ & $01-15$ & 15 a 31 \\
\hline Aurora & - & $\mathrm{X}$ & - & - & - & - & - & - \\
\hline Chimarrita & - & - & $\mathrm{X}$ & - & - & - & - & - \\
\hline Chiripá & - & - & - & - & - & - & - & $\mathrm{X}$ \\
\hline Coral & - & - & - & $\mathrm{X}$ & - & - & - & - \\
\hline Eldorado & - & - & - & - & $\mathrm{X}$ & - & - & - \\
\hline Maciel & - & - & - & $\mathrm{X}$ & - & - & - & - \\
\hline Marli & - & - & - & $\mathrm{X}$ & - & - & - & - \\
\hline Premier & - & $\mathrm{X}$ & - & - & - & - & - & - \\
\hline Vanguarda & - & $\mathrm{X}$ & - & - & - & - & - & - \\
\hline
\end{tabular}

Table 3. Accumulated precipitation ( $\mathrm{mm}$ ). Data from the closest meteorological station to the experimental area.

\begin{tabular}{|c|c|c|c|c|c|c|c|c|c|c|c|c|}
\hline Year & Jan. & Feb. & Mar. & Apr. & May & June & July & Aug. & Sept. & Oct. & Nov. & Dec. \\
\hline 2006 & 146.6 & 41.4 & 156.0 & 28.2 & 11.0 & 37.6 & 71.0 & 56.4 & 163.4 & 115.0 & 118.2 & 181.2 \\
\hline 2007 & 176.8 & 163.0 & 57.0 & 78.2 & 158.2 & 3.4 & 107.6 & 12.4 & 68.0 & 102.2 & 120.6 & 244.2 \\
\hline 2008 & 205.0 & 162.0 & 146.4 & 152.4 & 55.8 & 129.8 & 38.4 & 101.0 & 69.8 & 82.8 & 81.4 & 65.4 \\
\hline 2009 & 198.8 & 106.2 & 21.8 & 31.8 & - & - & - & - & - & - & - & - \\
\hline
\end{tabular}

Factors 1 and 2

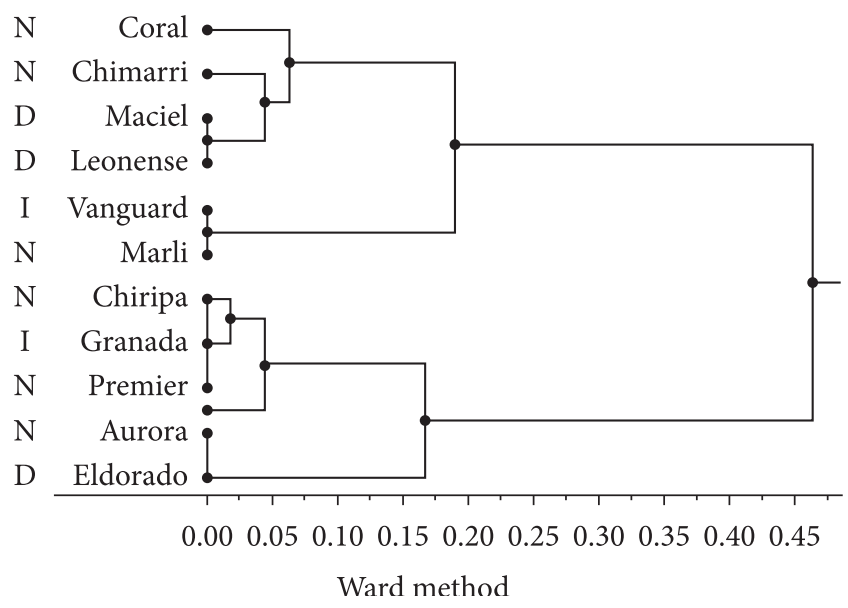

Figure 4. Dendrogram of grouping analysis plotted using the scores of the attributes appearance, flesh color, flesh firmness, juiciness, and flavor (Factors 1 and 2) obtained in the sensory analysis of eleven peach cultivars grown in the 2008/2009 season in the city of Lapa (PR, Brazil). $\mathrm{N}$ : in natura; D: double use, I: industry.

In both seasons, sensory analysis was performed by panelists who had their senses specially trained for this kind of analysis. Therefore, the different behavior among the groups, observed in Figures 1 and 2, cannot be justified by their scores; neither can such difference be determined by the possibility of crosspollination. Even if the plants distance would be enough for the occurrence of cross-pollination, fruits would have the "mother plant" features, no matter where the pollen comes from. The differences in the attributes between the seasons are probably due to the weather condition during the fruit maturation, i.e. between the end of August and the end of November (Table 2). Rainfall in September, October, and November 2007, was higher than that in the same period in 2008 (Table 3). Rainfall and temperature affecting physicochemical peach characteristics were also observed by Dolinski et al. (2005) in Chimarrita peaches assessed for three consecutive years.

\section{Conclusions}

- Chimarrita, Chiripá, and Coral peach cultivars obtained the best results in the sensory analysis.

- In natura peach consumers prefer sweet, soft, and juicy fruits.

- The analysis of aroma, flesh firmness, and flavor is enough for performing the sensory profile of peach fruits.

\section{References}

AGRIANUAL 2007: Anuário da agricultura brasileira. São Paulo: FNP Consultoria \& AgroInformativos, 2007. 516 p.

BIASI, L. A. et al. Cultivares de fruteiras de caroço. In: MONTEIRO, L. B. et al. Fruteiras de caroço: uma visão ecológica. Curitiba: UFPR, 2004. cap. 2, p.16-19.

CHITARRA, I. M. F; CHITARRA, A. B. Pós-colheita de frutas e hortaliças: fisiologia e manuseio, 2. ed. Lavras: UFLA, 2005.783 p.

DOLINSKI, M. A. et al. Produção, teor foliar e qualidade de frutos do pessegueiro 'chimarrita' em função da adubação nitrogenada na região de Lapa. Revista Brasileira de Fruticultura, v. 27, n. 2, p. 295-299, 2005. http://dx.doi.org/10.1590/S0100-29452005000200027

DUTCOSKY, S. D. Análise sensory de alimentos. Curitiba: Champagnat, 2007. 239 p. (Coleção Exatas, 4)

EMBRAPA - Clima Temperado. Produção de pessegueiro. Brasília, 2009. Disponível em: <http://sistemasdeproducao,cn ptia,embrapa,br/FontesHTML/Pessego/CultivodoPessegueiro/ cap16,htm>. Acesso em: 30 maio 2009. 
KAYS, S. J. Preharvest factors affecting appearance. Postharvest Biology and Technology, v 15, p. 233-247, 1998. http://dx.doi. org/10.1016/S0925-5214(98)00088-X

MARTINS, C. R. et al. Influência do manejo do solo na conservação, qualidade sensorial, teor de nutrientes e incidência de fitopatias e fisiopatias pós-colheita de pêssegos cv. Cerrito. Revista Brasileira de Fruticultura, v. 24, n. 2, p. 359-363, 2002. http://dx.doi. org/10.1590/S0100-29452002000200017

MATHIAS, C. et al. Efeito de porta-enxertos e espaçamento entre plantas na qualidade de pêssegos 'Aurora-1'. Revista Brasileira de Fruticultura, v. 30. n. 1, p. 165-170, 2008. http://dx.doi.org/10.1590/ S0100-29452008000100030

MATTHEIS, J. P.; FELLMAN, J. K. Preharvest factores influencing flavor of fresh vegetables. Postharvest Biology and Technology, v. 15, p. 228-230, 1998.

MENDONÇA, C. R. B. et al. Características sensoriais de compotas de pêssegos ligth elaboradas com sucralose e acesulfame-k. Ciência e Tecnologia de Alimentos, v. 25, n. 3, p. 401-401, 2005. http:// dx.doi.org/10.1590/S0101-20612005000300002

RASEIRA, M. C.; NAKASU, B. H. Cultivares: descrição e recomendação. In: RASEIRA, M. C. B.; MEDEIROS, C. A. A cultura do pessegueiro. Brasília: Embrapa Informação Tecnológica, 1998. cap. 3, p. 29-97.

ROMBALDI, C. V. et al. Ponto de colheita e período de armazenamento refrigerado na qualidade de pêssegos (Prunus persica, L,) de mesa, cv, Chiripá, Ciência Rural, v.31, n.1, p. 19-25, 2001. http://dx.doi. org/10.1590/S0103-84782001000100004

ROMBALDI, C. V. et al. Armazenamento de pêssegos (Prunus persica L.), cultivar Chiripá, em atmosfera controlada. Ciência Rural, v. 32, n. 1, p. 43-47, 2002. http://dx.doi.org/10.1590/S010384782002000100008
SAMS, C. E. Preharvest factors affecting postharvest texture. Postharvest Biology and Technology, v.15, p.249-254, 1998. http:// dx.doi.org/10.1016/S0925-5214(98)00098-2

SANDI, D. et al. Correlações entre características físico-químicas e sensoriais em suco de maracujá amarelo (Passiflora edulis VAR, flavicarpa) durante o armazenamento. Ciência e Tecnologia de Alimentos, v. 23, n. 3, p. 355-361, 2003. http://dx.doi.org/10.1590/ S0101-20612003000300010

STATICAL ANALYSIS SYSTEM INSTITUTE - SAS. SAS/STAT: User's guide; statistics. 5. ed. Cary: SAS Institute, 2000. 1985, p. 956.

SATO, G. S. Produção de pêssegos de mesa e para indústrias no Brasil. Informações Econômicas, v. 31, n. 6, p. 61- 63, 2001.

SISTEMA METEOROLÓGICO DO PARANÁ - SIMEPAR Tecnologia e Informações Ambientais. Dados metereológicos de araucária. Curitiba: SIMEPAR, 2009. 1 CD-ROM.

STONE, H.; SIDEL, J. L. Quantitative descriptive analysis: developments, applications, and the future. Food Technology, v. 52, n. 8, p. $48-52,1998$.

SUMITANI, H. et al. Changes in composition of volatile compounds in high pressure treated peach. Journal of Agricultural and Food Chemistry, v. 42, n. 3, p. 785-790, 1994. http://dx.doi.org/10.1021/ jf00039a037

TIBOLA, C. S.; FACHINELLO, J. C. Tendências e estratégias de mercado para a fruticultura. Revista Brasileira de Agrociência, v. 10, n. 2, p. 145-150, 2004.

TORALLES, R. P. et al. Um estudo para compreender a preferência e aceitação de consumidores de purês de pêssegos brasileiros. Revista Brasileira de Fruticultura, v. 28, n. 3, p. 397-401, 2006. http:// dx.doi.org/10.1590/S0100-29452006000300013

TREVISAN, R. et al. Atributos de qualidade considerados pelo consumidor de Pelotas/RS, na compra de pêssego in natura. Revista Brasileira de Agrociência, v. 12, n. 3, p. 371-374, 2006. 